Annals of Warsaw University of Life Sciences - SGGW

Land Reclamation No 45 (2), 2013: 193-205

(Ann. Warsaw Univ. of Life Sci. - SGGW, Land Reclam. 45 (2), 2013)

\title{
Effects of stabilization with cement on mechanical properties of cohesive soil - sandy-silty clay
}

WOJCIECH SAS ${ }^{1}$, ANDRZEJ GLUCHOWSKI ${ }^{2}$

Water Center Laboratory ${ }^{1}$, Department of Geotechnical Engineering ${ }^{2}$, Warsaw University of Life Sciences - SGGW

\begin{abstract}
Effects of stabilization with cement on mechanical properties of cohesive soil - sandy-silty clay. Ground improvement as a result of stabilization with cement has its impact on soft soils such as sandy clay in engineering constructions. Stabilized soils are also used in foundation design, where improvement of mechanical properties is needed. Because of these reasons, knowledge of physical and mechanical properties is needed. The relationship stress - strain of soils stabilized with cement is often unclear and strength characteristics need to be clear. In this paper results of physical and mechanical properties soil stabilized with cement are presented.
\end{abstract}

Key words: stabilization, cement, low liquid limit, cohesive soil, unconfined compressive test

\section{INTRODUCTION}

Problematic soils, such as fine-graded soils, are subjected to improving of their properties to obtain the best mechanical conditions. Geotechnical properties of soil used in a range of constructions must meet many requirements and fit technical descriptions, such as WT-4 proposed by Polish highway organization (GDDKiA) as the guide for test laboratories of soil quality.

One of many ways to obtain this demand is stabilization. Weak soils stabilized chemically with stabilization media such as lime or cement can highly improve mechanical characteristic of soil such as bearing capacity. Unfortunately impact of physical soil properties on stabilization process is still unclear. Underestimation of stabilization agents, in this case cement, may result in lowering of mechanical properties or cause shrinkage cracks. For proper support of wheel loads, these threats must be resolved.

Chemical stabilizations in general are based on mixing of stabilization agent with natural soils in order to improve strength properties of stabilized soil. More specifically, stabilization agent creates bonds between clay particles, removes excess moisture from soil and fills empty voids in soil skeleton.

Choosing of stabilization agent depends on many different factors. Between them, the trust factor is the most underestimated one. Application of such stabilization method must meet high standards of quality. Engineers need to be sure about mechanical properties and performing of stabilized material under moving wheel load.

Another type of problem is characteristic nature of clayey soils. In opposite to non-cohesive soils this type of material has poor strength properties and its application as building material creates many questions about performing under certain loading even after stabilization. 
Stabilization of soils with cement has positive impact on environment (Andromalos et al. 2000). Strength and mechanical properties are interrelated with the effectives of the cement and with the mineralogical composition of a clayey soil (Koncagül et al. 1999).

Clayey soils consist from montmorillonite (bentonite) or kaolinite (kaolin) mineral. These two minerals behave completely extreme perform under working load. More over, impact of the minerals on hydration of cement and hardening process are also different. Kaolin exhibits small impact on hardening process in opposite to bentonite, which needs large amounts of cement to obtain proper strength properties (Bell 1978).

In this article, results of unconfined compressive test were presented for a soil with low liquid limit of the sandy clay. The main aim of the paper was to obtain various properties of stabilized soil in diverse water and cement content. Also cyclic tests were conducted in order to find resilient behavior.

\section{LITERATURE REVIEW}

Recent developments in the field of stabilization of soils with cement and another chemical additions display usefulness of this technique in road constructions and foundation substructure development (Ismaiel 2006, Azadegan et al. 2013). Fast and well-known method for determining strength properties is obtaining Mohr-Coulomb parameters. In this theory shear strength is assumed to vary linearly due to applied normal stress in accordance with two commonly know parameters as the cohesion $(c)$ and the internal friction $(\varphi)$. Tests which were carried out by many researches (Ismail et al. 2002, Lo et al. 2003) based on triaxial tests. Difficulty and sophistication of triaxial equipment leads researches to find other methods of obtaining Mohr-Coulomb model parameters (Piratheepan et al. 2012). One of this ways is unconfined compressive strength test (UCS). This method however has its weak points. It has been well discerned that Mohr-Coulomb envelope becomes non-linear in low confining stress. This fact results in decrease of cohesion and increase of friction angle. For cemented sands this rule leads to significant over estimation of the cohesion.

According to this theory, mechanical prosperities are bounded with cohesion and friction. In case of simple loading of soil sample with applied stress $(\sigma)$, the shear stress $\left(\tau_{\max }\right)$ is presented from Coulomb theory, by the following equation:

$\tau_{\max }=c+\sigma \tan \varphi$

where:

$c$-cohesion,

$\varphi$ - internal friction angle,

$\sigma$-applied normal stress.

In Mohr-Coulomb extension for soils: $\left(\sigma_{1}-\sigma_{3}\right)=2 c \cos \varphi+\left(\sigma_{1}+\sigma_{3}\right) \sin \varphi$

where:

$\sigma_{1}, \sigma_{3}-$ major and minor principal stress respectively.

This well known theory is widely used by engineers in common practice mostly because of the fact of good prediction of strength behavior to complexity of obtaining needed data. However in Mohr-Coulomb theory to find strength 
parameters, triaxial test with estimated $\sigma_{1}$ and $\sigma_{3}$ is needed.

Pore pressure and permeability also changes during stabilization and this phenomenon makes it difficult to measure these factors during triaxial test.

Cement treated soils which are used in road construction are characterized by the increase of strength. Simple method to find this occurrence is unconfined compressive strength test (UCS). The following relationships proposed by Thompson (1966) can be used to define the cohesion and modulus of elasticity of lime treated soils based on unconfined compressive strength, respectively:

$$
\begin{aligned}
& c=\left(9.3+0.292 \frac{\sigma_{c}}{6.895}\right) \cdot 6.895 \\
& E=\left(9.98+0.1235 \frac{\sigma_{c}}{6.895}\right) \cdot 6.895
\end{aligned}
$$

where:

$c$ - cohesion (kPa),

$E$ - modulus of elasticity (kPa),

$\sigma_{c}-$ unconfined compressive strength $(\mathrm{kPa})$.

Observation of increasing mechanical parameters lead to conclusion that fine-graded soils yields a substantial increase in cohesion and less improvement in internal friction angle (Thompson 1966, Muhunthan and Sariosseiri 2008). This statement indicates that stabilization displays brittle behavior. Cement treated soils exhibit significant increase in compressive strength under UCS test, which varies from 40 times for fine-graded soils to 150 times for coarse-graded soils (Mitchell 1976).
Well established cement stabilization during past decades leads to proposing many empirical equations which describe changes of mechanical properties from curing time.

One of useful formula (5) presented by Mitchell (1976) allows us to calculate the increase of unconfined compressive strength considering the time of stabilization:

$$
\left(\sigma_{c}\right)_{d}=\left(\frac{\left(\sigma_{c}\right)_{d_{0}}}{6.895}+K \cdot \log \left(\frac{d}{d_{0}}\right)\right) \cdot 6.895
$$

where:

$\left(\sigma_{c}\right)_{d}$ - unconfined compressive strength at age of $d$-days $(\mathrm{kPa})$,

$\left(\sigma_{c}\right)_{d_{0}}$ - unconfined compressive strength at age of $d_{0}$-days $(\mathrm{kPa})$,

$K$ - material factor $(K=70 C$ for fine-graded soils and $K=10 \mathrm{C}$ for coarse soils),

$C$ - cement content (\%).

Because of brittle characteristics of soil stabilized with cement, which manifest as curing time increases, unconfined compressive strength increases, while the decrease of strain adequate to peak stress can be a statement that behavior of soft clay changes from normally consolidated to overconsolidated (Bergado et al. 1996).

This fact states stabilized soils with cement as soft rock corresponded with this material by brittle and higher tensile strength than porous materials. Tensile strength of stabilized soils is problematic because it often gives different results of internal friction angle and cohesion for the same material (Muhunthan and Sariosseiri 2008). 
Failure criterion (6) for soft rock considering tensile strength as important factor having impacted on strength parameters of shallow soft rocks proposed by Johnston and Chiu (1984):

$\sigma^{\prime}{ }_{1 N}=\left(\frac{M}{B} \sigma_{3 N}^{\prime}+1\right)^{B}$

where $M, B$ are constants representing general trends for which decreasing of $B$ parameter shear strength and increasing of $M$ parameter strength as well. $M$ also varies from rock type.

If $\sigma^{\prime}{ }_{3 N}=0$ gives the unconfined compressive strength and if $\sigma^{\prime}{ }_{1 N}=0$ assuming that $\sigma_{3 N}^{\prime}=\sigma_{t}^{\prime}\left(\sigma_{t}^{\prime}-\right.$ tensile strength $)$ then the ratio of UCS and uniaxial tensile strength can be expressed as:

$\frac{\sigma_{c}^{\prime}}{\sigma_{t}^{\prime}}=-\frac{M}{B}$

One of the advantages of this relationship is that it can be fitted to a wide range of strength envelope shapes by changing the power index $B$. By stating that $B=1$ it's possible to make the envelope linear: $\sigma_{1 N}^{\prime}=M \sigma_{3 N}^{\prime}+1$

which for

$M=\frac{1+\sin \varphi^{\prime}}{1-\sin \varphi^{\prime}}$

corresponds exactly to the normalized linear Mohr-Coulomb criterion. For clay soils and rocks calculation of $M$ and $B$ parameters are represented by followed equations:

$B=1-0.0172\left(\log \sigma_{c}\right)^{2}$

$\mathrm{M}=2.065+0.276\left(\log \sigma_{c}\right)^{2}$

where $\sigma_{c}$ is in $\mathrm{kPa}$.

\section{MATERIALS AND METHODS}

The tests were conducted on soil which was collected from an 80-cm-deep earthwork construction site. Conducted tests of sieve and aerometric (Bouyoucos method, using a modification made by Casagrande) analysis classified material as sandy-silty clay (sasiCl), in accordance with PN-EN ISO 14688:2006. Test results are shown in Figure 1. Studies

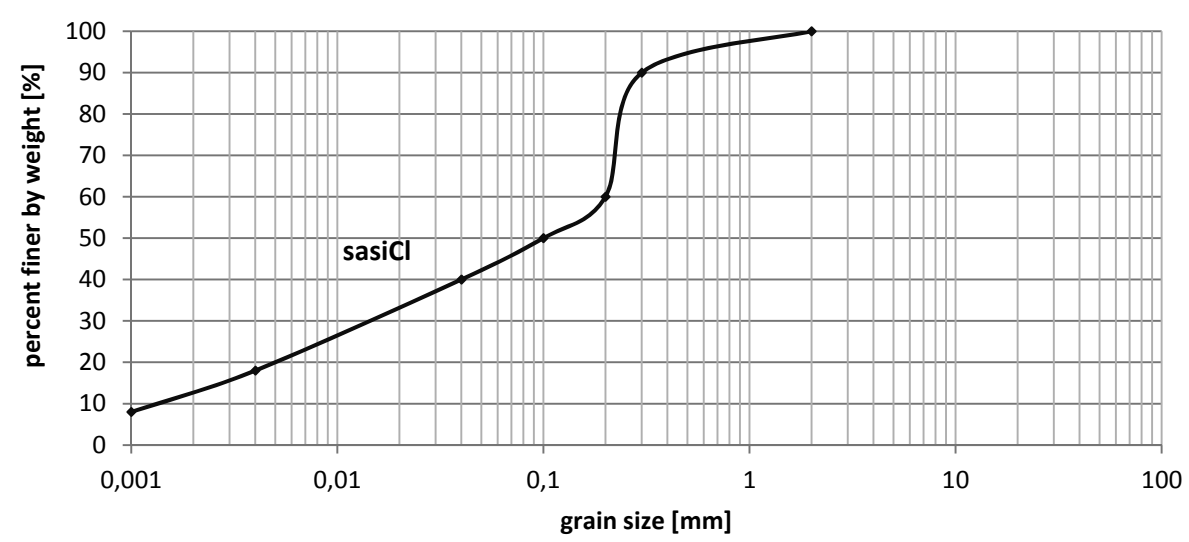

FIGURE 1. Particle size distribution of tested soil 
performed under existing Polish standards (PN-B-02480, PN-B-02481, PN-B-03020, PN-B-06050, PN-S-02201, PN-S-02205, PN-S-96011, PN-EN ISO 14688:2a, PN-88/B-04481).

Stabilization medium used for stabilization was Portland cement CEM I. Portland cement was obtained as common industrial package from ordinary building material store.

Preformed UCS tests specimens were prepared on accordance with existing Polish codes procedures. Compaction of specimens for UCS test was performed to obtain $0.59 \mathrm{~J} / \mathrm{cm}^{3}$ compaction energy with including optimal moisture content.

Estimation of liquid limit were conducted in Casagrande apparatus, with the use of soil paste. On the basis of six tests performed on differing moisture content, plot of liquid limit was made (Fig. 2). Estimated liquid limit was $18.7 \%$. Such range of liquid limit classifies this soil as clay with low plasticity.

\section{RESULTS}

Results of the Proctor test are presented in Figure 3. The test was conducted by compaction in the Proctor mold, with volume being equal $2.2 \mathrm{dm}^{3}$, by using standard energy of compaction, which is $0.59 \mathrm{~J} / \mathrm{cm}^{3}$. Optimum moisture content for sandy-silty clay was $10.7 \%$ and maximum dry density of optimum moisture content reached $2.18 \mathrm{~g} / \mathrm{cm}^{3}$.

The Proctor test was also performed for soil stabilized with cement. Tests were conducted for soil with 6 and $8 \%$ and of cement content. Results are presented in Figures 4 and 5.

Results of the Proctor test present the impact of cement content on optimum moisture content. For sandy-silty clay with $6 \%$ added lime, optimum moisture content was $11.41 \%$, while maximum dry density reached $2.09 \mathrm{~g} / \mathrm{cm}^{3}$. For specimens with $8 \%$ lime content and optimal moisture content at $11.53 \%$, maximum dry density was equal $2.25 \mathrm{~g} / \mathrm{cm}^{3}$. Figure 5 presents a $3 \mathrm{D}$ visualization of these variables. The graph surface analysis led

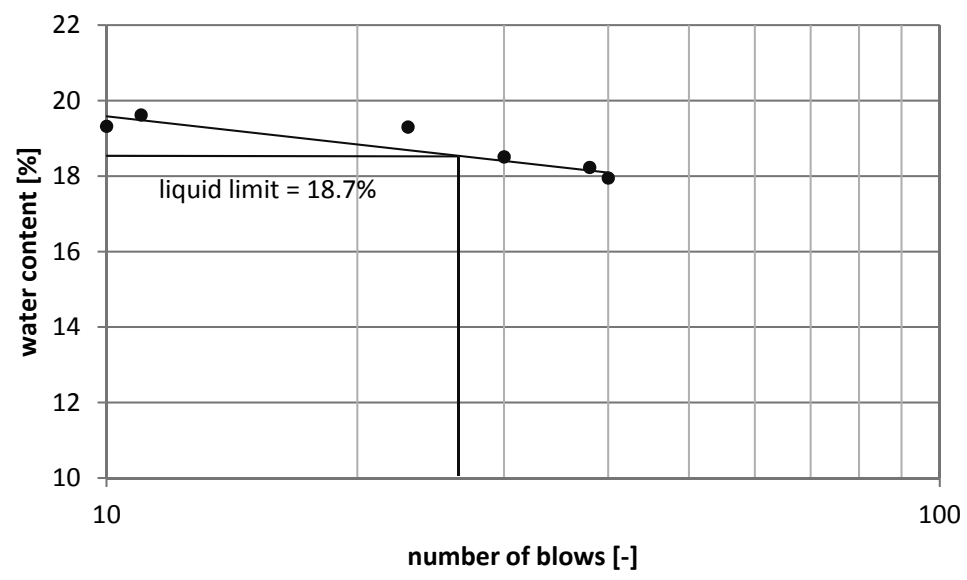

FIGURE 2. Liquid limit estimation test results 

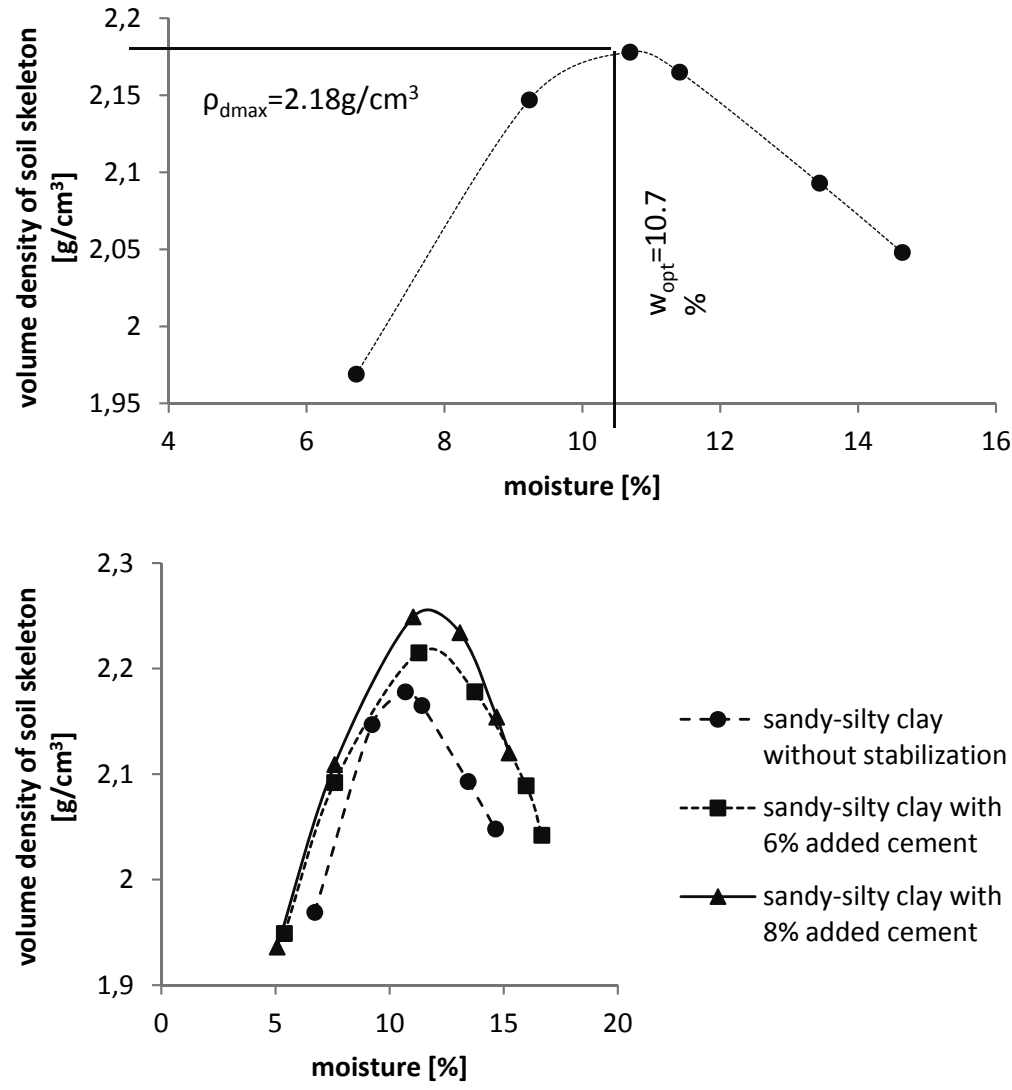

- - sandy-silty clay without stabilization

---1-- sandy-silty clay with $6 \%$ added cement

$\longrightarrow$ sandy-silty clay with $8 \%$ added cement
FIGURE 3. The

Proctor test results for sandy-silty clay

FIGURE 4. Results of the Proctor test for soil with varying cement content

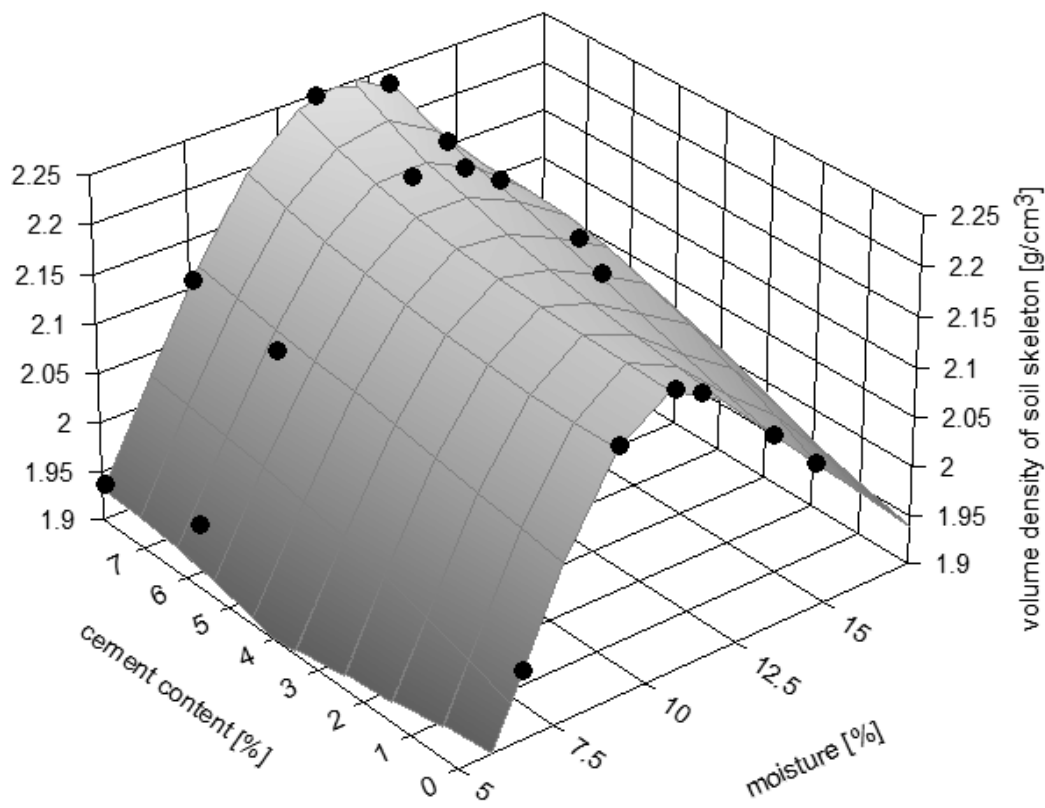

FIGURE 5. 3D plot of specimen dry density in soil with varying cement and water content 
to estimate an equation containing variables considering water and lime content. Equation (12) presents formula for calculating the density of soil $(z)$ under with varying cement $(y)$ and water content $(x)$ expressed as a percentage value:

$z=\frac{\mathrm{a}+\mathrm{cln} x+\mathrm{e} y+\mathrm{g}(\ln x)^{2}+\mathrm{i} y^{2}+k y(\ln x)}{1+\mathrm{b} \ln x+\mathrm{d} y+\mathrm{f}(\ln x)^{2}+\mathrm{h} y^{2}+\mathrm{j} y \ln x}$

Where letters from a to $\mathrm{k}$ are constants: $\mathrm{a}=1.719813971 ; \mathrm{b}=-0.78993667$; $\mathrm{c}=-1.33559312 ; \mathrm{d}=0.017226708 ;$ $\mathrm{e}=0.036358714 ; \mathrm{f}=0.163301429$; $\mathrm{g}=0.27483358 ; \mathrm{h}=-0.00069101 ;$ $\mathrm{i}=-0.00147716 ; \mathrm{j}=-0.00408803$; $\mathrm{k}=-0.00826438$. For this equation, the $\mathrm{R}^{2}$ is 0.995 . Equation (10) led to establishing the optimal water and cement content for tested sandy-silty clay, by fixing maximum dry density. Comparison of optimal moisture and cement content is presented on Figure 6. Estimated equation for this relationship $y=0.0733 x+10.95$ with $\mathrm{R}^{2}$ equal 0.997 . Next calculation was conducted by as- sumption taken from Polish code (13) for optimal water content for soils stabilized with lime (PN-S-96011), which is as follows:

$w_{\mathrm{opt}}^{w}=w_{\mathrm{opt}}^{g}+1.5+0.4 D$

where:

$w_{\mathrm{opt}}^{w}$ - optimum moisture content for the mixture, constant $(\%)$, $w_{\mathrm{opt}}^{g}$ - optimum moisture content before the addition of lime,

$D$ - lime content (\%).

These two results (Fig. 6 and eq. 13) make it possible to estimate optimal moisture content for soil stabilized with cement. Equation (14) presents this relationship:

$w_{\mathrm{opt}}^{c}=w_{\mathrm{opt}}^{g}+0.0733 D$

where:

$w_{\mathrm{opt}}^{c}-$ optimum moisture content for the mixture, constant (\%),

$w_{\mathrm{opt}}^{g}$ - optimum moisture content before the addition of lime, $D$ - lime content (\%).

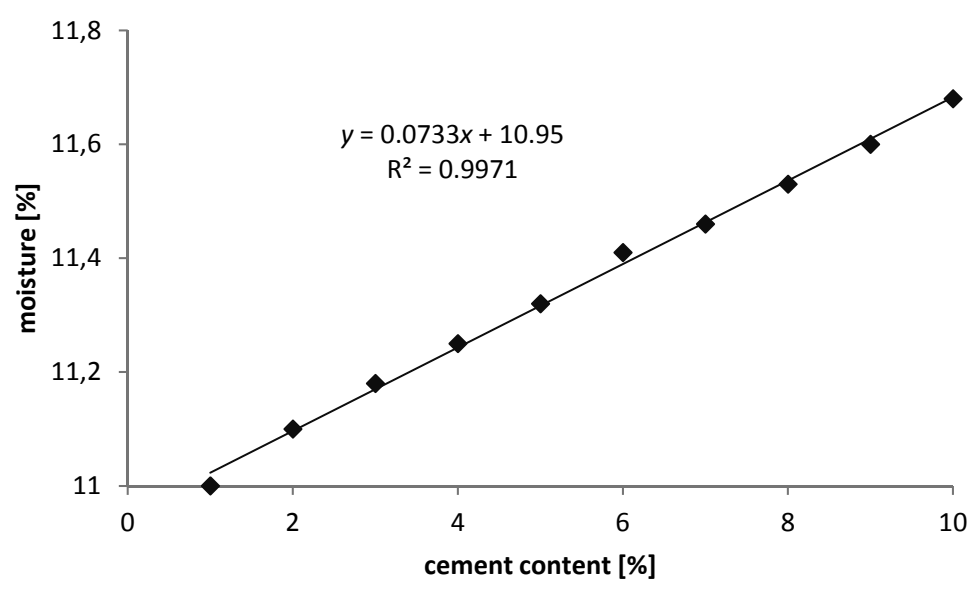

FIGURE 6. Results of optimal condition calculations for the mixture of sandy-silty clay, water and cement, and calculations based on the Polish standard and previous results 
It is necessary to mention that equation (11) is valid for cohesive soils with low liquid limit. Previous tests on soils stabilized with lime (Sas et al. 2013) confirmed that impact of clay and silt fraction on optimal moisture content for stabilized soils is significant and this surmise is valid also for soils stabilized with cement.

Study on compressive strength of stabilized specimens during various stages of stabilization, after 7 and 28 days, with variant moisture content (soaked, un-soaked). Obtained results are presented in Figures 7 and 8. Specimens were prepared in Proctor's mould in optimal moisture content and compressive strength tests were performed on stress - strain registration controller. Soaked specimens were stored in water until test.

Figure 7 presents compressive strength coefficient after stabilization with change of optimum moisture content with $6 \%$ cement added. Plot of this data clearly shows that compressive strength coefficient depends on the stabilization time for un-soaked samples. For soaked samples dependence of time of stabilization on the increase of compressive strength is clear. Results of test on Figure 7 show also convergence on $7^{\text {th }}$ day after stabilization of compressive strength. An important impact of moisture content can also be noted. Lastly, compressive strength coefficient rises in both cases but for un-soaked specimens after 28 days it reaches 2.838 from 1.047 at $7^{\text {th }}$ day. Soaked samples respectively give 1.516 and 1.024 .

On Figure 8 impact of saturation was analyzed. Soaked samples assumed to have $100 \%$ moisture and representing the results for soaked and un-soaked specimens in various time of stabiliza-

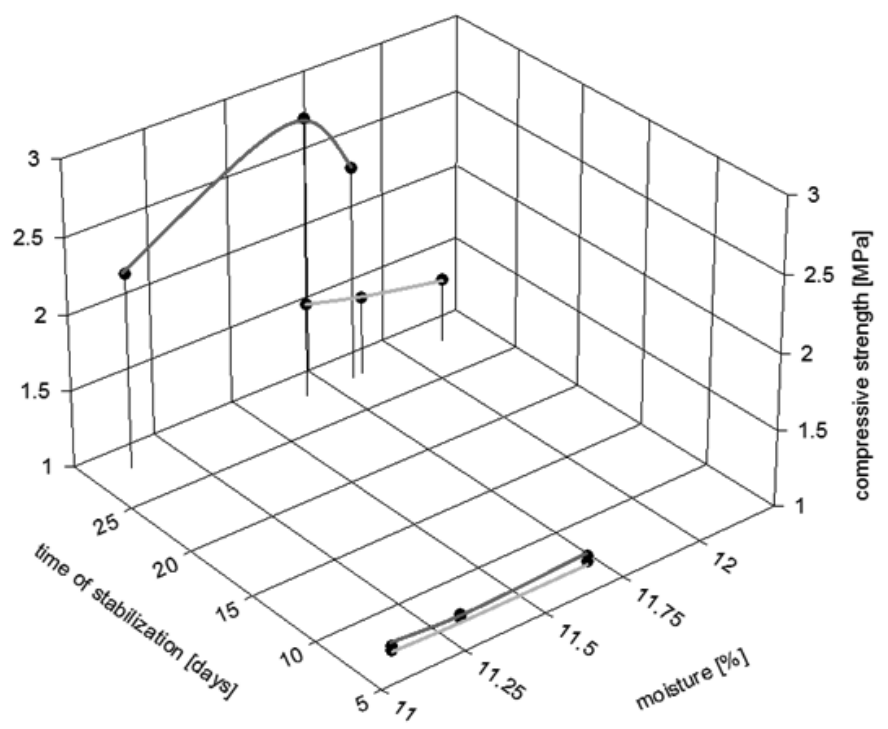

FIGURE 7. 3D plot of specimen compressive strength in soil with varying time of stabilization and compaction moisture for specimen with $6 \%$ cement added. Black color denotes un-soaked samples, grey color refers soaked specimens 


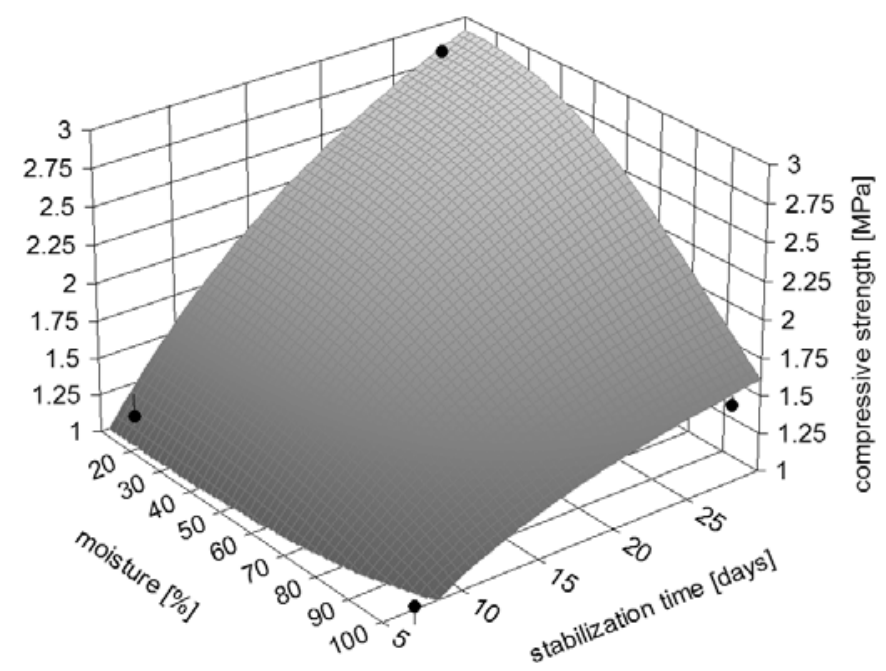

FIGURE 8. 3D plot of specimen compressive strength in soil with varying time of stabilization and water content for specimen with $6 \%$ cement added

tion were use to find formula describing this phenomena.

Equation (15) presents formula for calculating the compressive strength of sandy-silty clay $(z)$ with varying time after stabilization $(y)$ and water content $(x)$, expressed as a percentage value:

$$
z^{-1}=\mathrm{a}+\mathrm{b} x^{3}+\frac{\mathrm{c}}{y}
$$

Where letters from a to $\mathrm{c}$ are constants: $\mathrm{a}=0.194743202 ; \mathrm{b}=$ $=0.0000002776 ; \quad \mathrm{c}=4.46434566$. For this equation the $\mathrm{R}^{2}$ value is 0.980 .

Equation (6) was applied to find maximal compressive strength in various stages of stabilization in optimal moisture content. Results are presented on Figure 9.

Figure 9 presents results of calculation compressive strength with equation (5) proposed by Mitchell. Empty points denote results of the tests. For un-soaked specimens the equation works well. For soaked samples some modifications were needed to be made. To properly fit the curve of increasing compressive strength, factor $K$ was modified. New proposition is as follow:

$K=20 C$

where: $C$ - cement content (\%).

On Figure 10 results of compressive strength calculated by Mitchell equation (5) and tensile strength calculated by Johnston formula (7) were presented.

Johnston failure envelope was estimated by using UCS test results and obtaining results from Mitchell equations. At $7^{\text {th }}$ day of stabilization compressive strength was equal to $1.047 \mathrm{MPa}$. Corresponding tensile strength calculated from (7) equals $-0.211 \mathrm{MPa}$. For $28^{\text {th }}$ day of stabilization results are $2.838 \mathrm{MPa}$ and $-0.468 \mathrm{MPa}$ respectively.

Johnston failure criterion was also used to calculate changing of maximal major $\sigma_{1}$ and minor stress $\sigma_{3}$. Results are presented on Figure 11. 


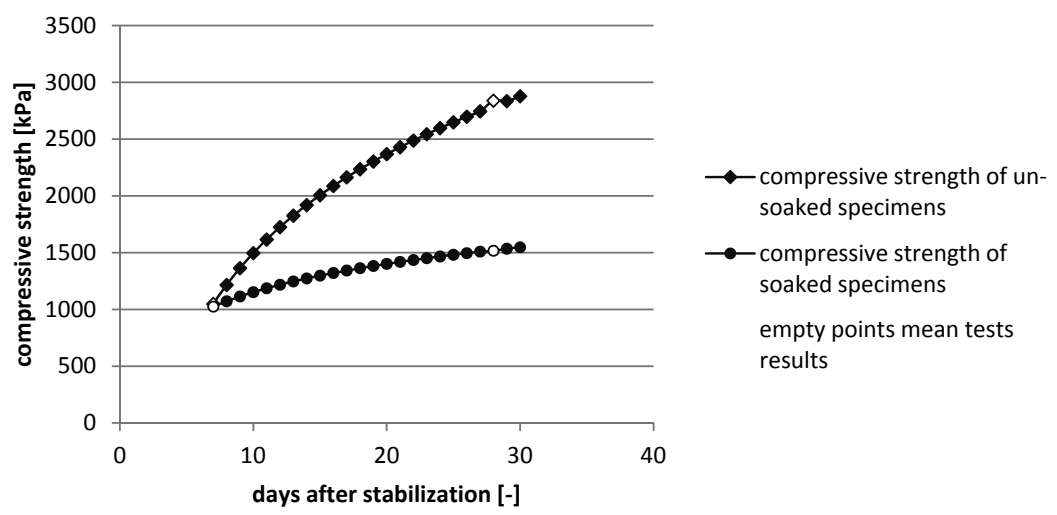

FIGURE 9. Results from calculating compressive strength changes of stabilized soil with $6 \%$ added cement sandy-silty clay in various stage of stabilization with equation (5)

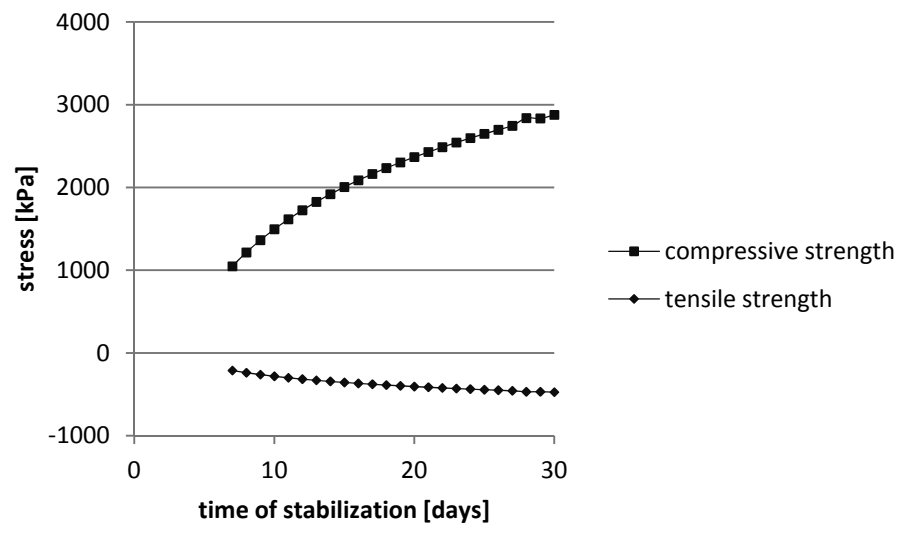

FIGURE 10. Results of calculations of tensile and compressive strength for un-soaked samples of sandy-silty clay stabilized with $6 \%$ cement added in various stage of stabilization

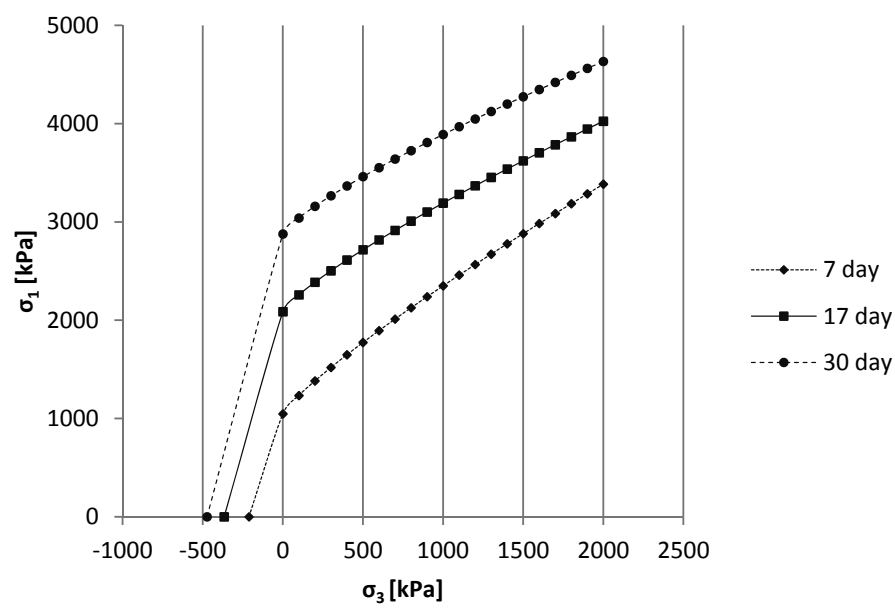

FIGURE 11. Results of calculation major and minor maximal stress from UCS test with Johnston formula 


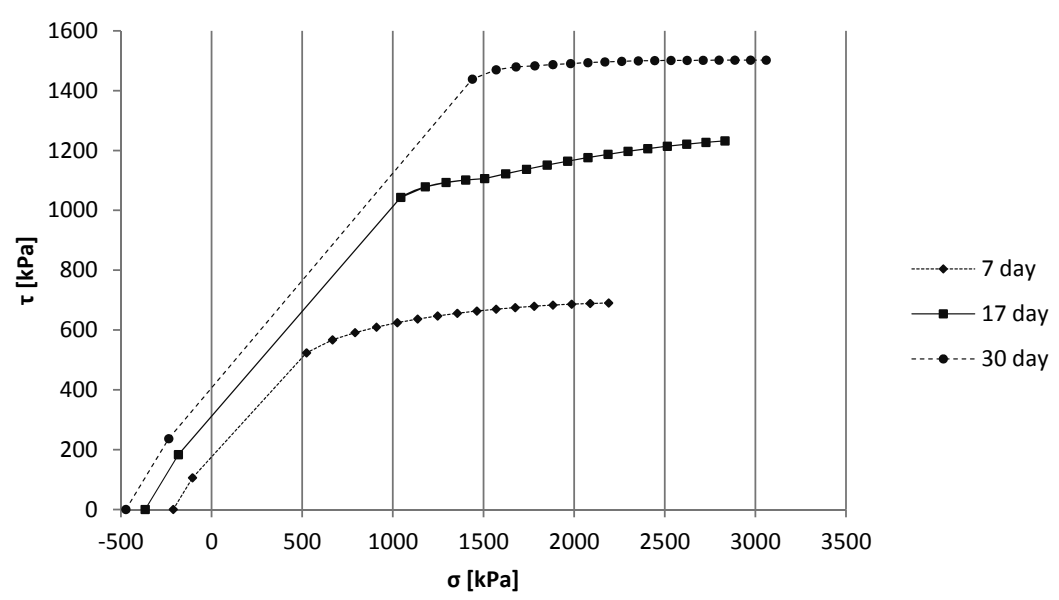

FIGURE 12. Results of calculation major and minor maximal stress from UCS test with Johnston formula in plot of normal stress-shear stress

Figure 11 shows rising of strength of stabilized material in time of stabilization factor. Increasing of strength concerns also compression and tension. For better understanding this relationship, plot of $\sigma_{1}$ and $\sigma_{3}$ against $\tau$ was made (Fig. 12).

On Figure 12 few relationships can be observed. With time of stabilization, strength parameters increase. But by assuming Johnston model of failure, we can observe constant shear stress with raised $\sigma_{3}$. Important conclusion from Figure 12 is different between cohesion obtained as result of UCS test and estimated from Johnston model. UCS test cohesion is equal half of maximal stress from this study. For this case, is equal $523.5,1034,1483 \mathrm{kPa}$ for 7,17 and 30 days respectively. Results of calculations presents as follow: 170, 310 and $395 \mathrm{kPa}$ respectively. Differences between this results are 3.5 times bigger if we consider UCS test as reference.

\section{CONCLUSIONS}

The research conducted in this paper and analysis of the mechanical properties of sandy-silty clay stabilized with lime, lead to the following conclusions:

1. Optimum moisture content obtained during the Proctor test for low liquid limit sandy-silty clay stabilized with cement addition allowed to calculate equation (14) which can be used to find optimal moisture content of soil stabilized with cement addition.

2. Cohesive soils as sandy-silty clay stabilized with cement, can be treated as soft rock due to its brittle behavior.

3. Relationship proposed in equation (15) allows calculation of compressive strength baseding on time of stabilization for soaked and un-soaked samples.

4. Mitchell relationship gives reasonable data of calculations of compressive strength in various time of stabilization for un-soaked samples. For soaked specimens modification of this relationship was proposed (16). 
5. For calculating of cohesion of soils stabilized with cement Johnston formula is more suitable than common procedure used in UCS tests. Results are 3.5 times bigger in case of UCS test than results from calculation of Johnston equation.

\section{REFERENCES}

ANDROMALOS K.B., HEGAZY Y.A., JASPERSE B.H. 2000: Stabilization of soft soils by soil mixing. Proceedings of the Soft Ground Technology Conference, Noorwijkerout, Netherland.

AZADEGAN O., YAGHOUBI E., Li J. 2013: Evaluation of the Performance of Lime and Cement Treated Base Layers in Unpaved Roads. The Electronic Journal of Geotechnical Engineering 18: 1593-1602.

BELL F.G. 1978: Foundation Engineering in Difficult Ground. Butterworths, London. BERGADO D.T., ANDERSON L.R., MIURA N., BALASUBRAMANIAM A.S. 1996: Soft ground improvement. ASCE Press, Reston.

ISMAIEL H.A.H. 2006: Treatment and Improvement of the Geotechnical Properties of Different Soft Fine-grained Soils Using Chemical Stabilization. Shaker, Aachen.

ISMAIL M.A., JOER H.A., SIM W.H., RANDOLPH M. F. 2002: Effect of Cement Type on Shear Behavior of $\mathrm{Ce}$ mented Calcareous Soil. ASCE's Journal of Geotechnical and Geoenvironmental Engineering 128(6): 520-529.

JOHNSTON I.W, CHIU H.K. 1984: Strength of weathered Melbourne mudstone. Journal of Geotechnical Engineering 110(7): 875-898.

KONCAGÜL C.E., SANTI M.P. 1999: Predicting the unconfined compressive strength of the Breathitt shale using Slake durability, Shore hardness and rock structural properties. International Journal of Rock Mechanics and Mining Sciences 36: 139-153.
LO S.C.R., LADE P.V., WARDANI S.P.R. 2003: An Experimental Study of the Mechanics of Two Weakly Cemented Soils. Geotechnical Testing Journal ASTM 263: $1-14$

MITCHELL J.K. 1976: The properties of cement-stabilized soils. Proceeding of Residential Workshop on Materials and Methods For Low Cost Road, Rail, and Reclamation Works, Australia: 365-404.

MUHUNTHAN B., SARIOSSEIRI F. 2008: Interpretation of Geotechnical Properties of Cement Treated Soils. Research Report WA-RD 715.1 Pullman Washington State University, Washington.

PIRATHEEPAN J., GNANENDRAN C., ARYLRAJAH A. 2012: Determination of $\mathrm{c}$ and $\varphi$ from IDT and Unconfined Compression Testing and Numerical Analysis. Journal of Materials in Civil Engineering 24(9): 1153-1164.

PN-88/B-04481: Grunty budowlane. Badania próbek gruntu.

PN-B-02480: Grunty budowlane - Określenia, symbole, podział i opis gruntów.

PN-B-02481: Geotechnika - Terminologia podstawowa, symbole literowe i jednostki miar.

PN-B-03020: Grunty budowlane - Posadowienie budowli - Obliczenia statyczne i projektowanie.

PN-B-06050: Geotechnika - Roboty ziemne - Wymagania ogólne.

PN-EN 1997-1: Projektowanie geotechniczne - Część 1: Zasady ogólne.

PN-EN 1997-2: Projektowanie geotechniczne - Część 1: Rozpoznanie i badanie podłoża gruntowego.

PN-EN ISO 14688:2a : Badania geotechniczne Oznaczanie i klasyfikowanie gruntów. Część 2: Zasady klasyfikowania.

PN-S-02201: Drogi samochodowe - Nawierzchnie Drogowe - Podział, nazwy i określenia.

PN-S-02205: Drogi samochodowe - Roboty ziemne - Wymagania i badania.

PN-S-96011: Drogi samochodowe - Stabilizacja gruntów wapnem do celów drogowych. 
PN-S-96012: Drogi Samochodowe - Podbudowa i ulepszone podłoże $\mathrm{z}$ gruntu stabilizowanego cementem.

SAS W., MARGIELSKI J., GŁUCHOWSKI A. 2013: Estimation Of Mechanical Properties Cemically Stabilized Soil With Lime. Annals of Warsaw University of Life Sciences. Land Reclamation 45(1): 27-39.

THOMPSON M.R. 1966: Shear strength and elastic properties of lime-soil mixtures. Highway Research Record, Washington, D.C., 139: 1-14.

WT-4: Mieszanki niezwiązane do dróg krajowych. GDDKiA.

Streszczenie: Wplyw stabilizacji cementem na właściwości mechaniczne zagęszczonego gruntu spoistego - iłu pylastopiaszczystego. Stabilizacja gruntów cementem pozwala na zastosowanie słabych gruntów spoistych, np. iłu pylastopiaszczystego w konstrukcjach inżynierskich, takich jak nasypy albo podłoże gruntowe konstrukcji drogowych. Grunty stabilizowane wykorzystuje się również w fundamentowaniu, gdzie wymagane jest ulepszenie właściwości mechanicznych gruntów pod fundamentem. $\mathrm{Z}$ tego powodu istot- ne jest posiadanie wiedzy na temat właściwości mechanicznych gruntów stabilizowanych oraz ich charakterystyk naprężenia - odkształcenia, co w przypadku gruntów stabilizowanych cementem jest problematyczne. W artykule przedstawiono wyniki badań fizycznych i mechanicznych właściwości gruntu stabilizowanego cementem.

Stowa kluczowe: stabilizacja, cement, niska granica płynności, grunty spoiste, jednoosiowe ściskanie

MS. received in December 2013

\section{Authors' addresses:}

\section{Wojciech Sas}

Laboratorium - Centrum Wodne SGGW

ul. Ciszewskiego 6, 02-776 Warszawa

Poland

e-mail: wojciech_sas@sggw.pl

Andrzej Głuchowski

Wydział Budownictwa i Inżynierii Środowiska SGGW

Katedra Geoinżynierii

ul. Nowoursynowska 159, 02-776 Warszawa

Poland

e-mail: andrzej_gluchowski@sggw.pl 